\title{
Senior Projects in a Rural School
}

Technology and a school-university partnership enabled high school faculty members to implement the Senior Project. Matt Rickey and Glenda Moss describe the process of change, the project requirements, and the learning that resulted for students and faculty.

like to think of East Noble High School (ENHS) as a high-tech rural school. We have one of the top tech departments in the state-four computer labs, two designed for research and composition; student access to email and the Internet; and programs such as Microsoft Word, PowerPoint, and Excel. In this blue-collar factory and farming area, we are rural but we are not isolated or void of technology. Writing grants and reaching out to philanthropists and a neighboring university helped us to integrate technology and research into our rural context to successfully implement the Senior Project in our school in 2001.

Like other schools, ENHS is experiencing the growing pains of change as we work to improve thinking and writing skills in a student population with a range of abilities. The Senior Project helps us meet these goals. However, the implementation would have been much more difficult, if not impossible, without the learning partnership created between ENHS and the School of Education at Indiana University Purdue University Fort Wayne (IPFW). Coauthor Glenda Moss, assistant professor of secondary education, mentored me in the process of using narrative methods to analyze my experiences of choosing and implementing the Senior Project program at ENHS and writing this article.

\section{A Historical Perspective}

The Senior Project was introduced in 1986 by a group of English teachers who worked at South Medford High School in Medford, Oregon. We learned about it at a National Staff Development Council seminar on educational innovations, held in San Antonio, Texas, in the summer of 2000. Teachers who have used this innovation claim that the Senior Project allows all students "from basic to advanced, rich and poor, socialite and outcast" (Summers 63) to be involved in an opportunity to control what they will study in depth during their final year of high school. While Summers indicated that some students could struggle with the paper, she noted that they typically excel with the physical portion and the presentation.

Summers saw the project as a way of bringing seniors together in contrast to the fragmentation that resulted from tracking. Many schools, such as ours, had been separating students academically—college bound versus noncollege bound.

In 2004, the basic model developed by these innovators is being implemented in high schools across the nation. Chadwell listed six goals for the project:

1. To provide a long-term, challenging, multidisciplinary activity to enhance a limp second semester senior experience. ...

2. To hold graduating seniors accountable for twelve years of schooling and to demonstrate to the public that learning did take place....

3. To insist and expect seniors to model active learning focused on a long term educational goal. ...

4. To allow seniors to make some choices....

5. To involve the community in an academic manner. ...

6. To provide the staff with a sense of accomplishment and a clear idea of needed improvements by showcasing the results of their efforts. (8) 
Chadwell further indicated that the Senior Project has a significant effect on younger students as they observe the seniors in their preparation of the three phases of the project: the research paper, the physical project, and the oral boards. The Senior Project provides students with the opportunity to see that the seemingly insignificant objectives they may learn in their early high school years actually build and lead to greater, more important objectives, including the ability to write a lucid, detailed, organized, and documented paper; the ability to create a physical project that is in some way linked to the paper; and the ability to speak of the experience confidently to a board of teachers and community members.

ENHS adopted the Senior Project curriculum in 2001 and has witnessed two years of growth in research and writing. We continue to polish our program, which will always be a work in progress. We have made some significant changes from the first year and will continue to implement the modifications necessary to make a complex program work. A description of our process, including the surprises, may help others who are considering adopting a Senior Project curriculum.

\section{Student Resistance and Acceptance}

My life experience did not prepare me for students' initial reactions to the Senior Project. I was raised in a blue-collar environment, which was guided by the philosophy that a person must work hard and be willing to sacrifice to succeed. My brothers and I paid for most of our college educations, worked hard, and sacrificed by paying bills well into our 20s. I was disappointed when most of my English 12 AP students complained about completing the Senior Project paper. I had had many of these students as juniors and thought we had connected on ideas regarding the true purpose of an education-learning to learn.

Most difficult for me was the apparent air of superiority that many of the AP seniors exhibited. Most seemed to think that the project was beneath them, that they had already proven themselves with high grades, and that the Senior Project should be solely intended for noncollege-bound students. Some AP students understood the purpose, tackled the job as an opportunity, and put forth their best effort to further prepare themselves for the rigors of college.
Still others indicated that it only proved that they could complete a paper in a day or two and thus were able to pass the minimum standards with relatively little effort. They rejected the "bureaucracy" of the process - unbending due dates and specific requirements regarding forms.

I am an idealist at heart, so I believed that when the students were told of the benefits the Senior Project would afford them in years to come-the knowledge that they are able to complete a detailed research paper accompanied by a physical component, that they are indeed able to speak comfortably in front of a small group of people, and that they are able to follow through on a project with hard and fast deadlines-they would be willing to give it a shot. While students completed the project, its requirement for graduation was a major complaint throughout
While students completed the project, its requirement for graduation was a major complaint throughout the process. In retrospect, I perceive this to have been resistance that accompanies most changes, especially when higher expectations are introduced. the process. In retrospect, I perceive this to have been resistance that accompanies most changes, especially when higher expectations are introduced.

While the attitudes of many AP students were problematic, the most uplifting part of the Senior Project came from some of the students who were not headed to a four-year college or university. Students who were headed to a two-year program, an apprenticeship, or the workplace realized that hard work does have its rewards. Some were seeing tangible proof of success for the first time. I could relate to these students.

I was not the best student when I was in high school (A's, B's, and a few C's), but I knew during my sophomore year that I wanted to teach high school English and social studies some day. Thus, I care about inspiring students, and I talk about the need for them to get more out of their education than simply grades or a degree. I avoid busywork in my classes and attempt to have frank discussions with the students about how class activities and assignments apply to their future. After teaching for more than twenty-two years, I was still naive enough to believe that the students would take what I had to say at face value and would appreciate the opportunity to learn through their Senior Projects. 
It was discouraging that students initially saw the Senior Project as a punishment rather than an opportunity. Again, part of this was the change process, as we are now beginning to see signs of students accepting the inevitability of the project. Students from the Class of 2004 are coming to me not to complain but rather to ask my opinion about the topics they are choosing for their Senior Projects. Students from the Class of 2005 were ninth graders during the inauguration of the project; as a result, they know that they will complete a Senior Project before they graduate. My desire is to have seniors (Class of 2004) lead in a positive way and set a good example for all students. I have been fortunate to have similar leadership afforded to me through a Senior Project partnership with Glenda at IPFW.

\section{School-University Partnership}

A core of teachers, including myself, presented the idea of the Senior Project to the faculty at ENHS and later to the school board for approval. Implementation began in the fall of 2001, bringing high school students, classroom teachers, preservice teachers, and a university professor into a collaborative learning partnership. Internally, teachers had designed a scoring rubric aligned with the Indiana State Standards but decided to look outside of the English department and school district for scorers.

Since one of the goals of the Senior Project experience is transitional-preparing students for college, post-high school job training, or entering the workforce-the teachers decided to ask IPFW to

\section{Just as the high school students had the opportunity to reflect on critical feedback from preservice teachers, the ENHS English teachers had the opportunity for professional development as they, too, received feedback on the scoring rubric.} become a partner in this project. A natural connection was made with the School of Education, where secondary preservice teachers learn to teach.

Silent coauthor of this paper, Glenda, a first-semester teacher educator in 2001, viewed this as a logical university-school partnership and service learning project, and she agreed to allow her preservice teachers to score the papers as a way to learn how to use rubrics to grade research project papers. Glenda saw this as an opportunity for preservice teachers to practice learning about assessment and reflect on the scoring as a form of portfolio assessment.

I visit Glenda's classes each semester and show her preservice teachers how to score the research essays using the rubric designed by the participating teachers from my school. A week later, I deliver the papers to Glenda's class and help supervise the preservice teachers as they gain hands-on experience scoring the senior research papers.

Preservice teachers score quite a number of papers. In the spring of 2002, nearly 234 graduating seniors completed a Senior Project. (A few were exempted-fifth-year seniors, emotionally handicapped students.) Every student who wrote the paper and completed rewrites passed the written portion of the Senior Project. These students also eventually passed the Oral Boards. The AP students were required to complete a physical portion of the project (a casual oral presentation with visuals for community members to experience), and all did so.

Just as the high school students had the opportunity to reflect on critical feedback from preservice teachers, the ENHS English teachers had the opportunity for professional development as they, too, received feedback on the scoring rubric. The initial scoring format was twofold: "YES Test" criteria (mechanics of a research paper-title, indentation, citation, works cited page, and so forth-that students had worked on throughout the semester with many intermediate due dates; see fig. 1) and writing rubric (see fig. 2). All of the students passed the minimum score of 50 percent on the rubric. At least 90 percent of the students had to make corrections based on the YES Test. The teachers examined the outcomes of the assessment process and addressed questions that arose regarding four issues: the presentation of the rubric to the preservice teachers, adding an additional level of assessment, the YES Test, and raising the minimum passing score to 60 percent.

The YES Test is now handled at the high school campus level, raising the initial quality of students' work. The process of feedback and revision for the papers and the Senior Project program resulted in higher-quality papers during the second year of implementation.

During the fall semester of the 2002-03 academic year, approximately 180 ENHS seniors completed the research paper with a high success rate on the minimum requirements of the rubric. Using their 
FIGURE 1. Research Paper YES Test

Modified 11/09/02

Student Name ID\# English Teacher

This will be the YES Test that will be worked on in your English class. For the research paper to be sent out to be scored, all of the following required components must be present. (All answers must be YES; one NO on the research paper due date renders this paper unacceptable and the student will be required to begin the research paper again with a new topic.)

1. Paper is typed YES NO

2. Paper is double-spaced throughout YES NO

3. Paper has 5-12 pages of body (does not include the "Works Cited" page) YES NO

4. 1" margins on all pages YES NO

5. Correct page numbering YES NO

6. Correct format for citations YES NO

7. First page of body set up correctly (Project info to the left, title centered) YES NO

8. Followed rules of indentation YES NO

9. Used readable/consistent reasonably sized font throughout the paper YES NO

10. Thesis statement is underlined YES NO

11. Graphs/Pictures/Sketches/Statistical Tables are in the appendix YES NO N/A

12. Minimum of five sources used YES NO

13. Used minimum one and maximum two interviews as a source YES NO

14. Avoided general encyclopedias YES NO

15. Used correct format on the "Works Cited" page YES NO

16. Student refrained from padding his/her "Works Cited" page YES NO

I created three hard copies of the paper:

- Two for outside scorers, identified by my student ID YES NO

- One for Mr. Rickey with student's printed name at the top of page 1 YES NO English Teacher's Initials

The English teacher's initials indicate that the student's paper has passed this YES Test and is ready to be sent out for scoring.

- Please attach this YES Test to the front of the research paper that you give to Mr. Rickey. This is the paper that will be scored by IPFW.

- You should always have a hard copy for your protection. Ultimately, you are responsible for the paper if it is lost.

- See the sample paper entitled "Infallible Obedience" for an example of how your paper should look.

- All rules apply unless you receive permission from your English teacher for a change. If you do make some kind of change from the norm, it should be noted next to the proper line above and signed by your teacher. For example, if you used a specialized encyclopedia, circle "NO" and write "with permission" followed by the teacher's signature.

- You are also to keep a hard copy of all the sources you used. Whether you used the Internet, completed an interview (the questions you asked and the answers you received), used a page or two from a book or magazine, you must have a hard copy as documentation. You may be called on to produce these for the sake of checking your paraphrasing. These hard copies will be placed in your portfolio along with the "cleaned-up" copy of your research paper. 
Student ID \#

Date Teacher ID \#

Modified 06/03/02 East Noble School Corporation

\begin{tabular}{|c|c|c|c|c|c|}
\hline $\begin{array}{l}1 \\
\text { IDEAS AND CONTENT }\end{array}$ & 2 & $\begin{array}{l}3 \\
\text { IDEAS AND CONTENT }\end{array}$ & 4 & $\begin{array}{l}5 \\
\text { IDEAS AND CONTENT }\end{array}$ & SCORE \\
\hline $\begin{array}{l}\text { Paper does not follow } \\
\text { thesis or there is no thesis }\end{array}$ & & $\begin{array}{l}\text { Paper strays from } \\
\text { thesis at times }\end{array}$ & & $\begin{array}{l}\text { Paper follows thesis/ } \\
\text { very focused }\end{array}$ & \\
\hline Little knowledge on the topic & & Knowledge of topic limited & & Knows topic well & \\
\hline Many details missing & & Skimpy supporting details & & Effective amount of details & \\
\hline Less than $70 \%$ paraphrased & & $70 \%-79 \%$ paraphrased & & $80+\%$ paraphrased & \\
\hline ORGANIZATION & & ORGANIZATION & & ORGANIZATION & \\
\hline $\begin{array}{l}\text { Little sense of direction } \\
\text { or sequence }\end{array}$ & & $\begin{array}{l}\text { Sequence somewhat } \\
\text { unclear, ineffective }\end{array}$ & & Effective sequence & \\
\hline $\begin{array}{l}\text { No clear beginning } \\
\text { or ending }\end{array}$ & & Weak start or finish & & $\begin{array}{l}\text { Clear sense of } \\
\text { beginning/end }\end{array}$ & \\
\hline $\begin{array}{l}\text { Details do not relate } \\
\text { to the topic }\end{array}$ & & Misplaced details & & Details organized & \\
\hline VOICE/WORD CHOICE & & VOICE/WORD CHOICE & & VOICE/WORD CHOICE & \\
\hline Major third-person violations & & Some third-person violations & & $\begin{array}{l}\text { Paraphrases are written } \\
\text { in third person }\end{array}$ & \\
\hline Flat, lifeless writing & & $\begin{array}{l}\text { Lacks a strong sense of personal } \\
\text { commitment, involvement }\end{array}$ & & $\begin{array}{l}\text { Enthusiasm, interest } \\
\text { are apparent }\end{array}$ & \\
\hline No personality/character & & $\begin{array}{l}\text { Communicates in routine } \\
\text { predictable fashion }\end{array}$ & & $\begin{array}{l}\text { Individualistic, engaging, } \\
\text { honest, sincere, candid }\end{array}$ & \\
\hline Imagery is weak or absent & & $\begin{array}{l}\text { General language } \\
\text { weakens imagery }\end{array}$ & & Strong, full, rich imagery & \\
\hline Limited vocabulary & & $\begin{array}{l}\text { Vocabulary is adequate, } \\
\text { ordinary }\end{array}$ & & $\begin{array}{l}\text { Accurate, interesting, lively vocab- } \\
\text { ulary, appropriate to the topic }\end{array}$ & \\
\hline MECHANICS/GRAMMAR & & MECHANICS/GRAMMAR & & MECHANICS/GRAMMAR & \\
\hline $\begin{array}{l}\text { Sentence structure } \\
\text { rambling, awkward }\end{array}$ & & Structure is usually correct & & $\begin{array}{l}\text { Structure and punctuation } \\
\text { effective }\end{array}$ & \\
\hline $\begin{array}{l}\text { Choppy, incomplete } \\
\text { sentences }\end{array}$ & & $\begin{array}{l}\text { Sentences sometimes awkward, } \\
\text { doesn't flow smoothly }\end{array}$ & & $\begin{array}{l}\text { Eloquent, easy to read, flows, } \\
\text { sounds natural when read aloud }\end{array}$ & \\
\hline No sentence variety & & Minimal sentence variety & & $\begin{array}{l}\text { Varied sentence structure } \\
\text { enhances paper, adds interest }\end{array}$ & \\
\hline Many mistakes in citations & & Some mistakes in citations & & Few mistakes in citations & \\
\hline $\begin{array}{l}\text { Numerous errors impair } \\
\text { readability (spelling, } \\
\text { punctuation, capitalization, } \\
\text { usage, paragraphing, grammar) }\end{array}$ & & $\begin{array}{l}\text { Errors may require pauses or } \\
\text { rereading (spelling, punctuation, } \\
\text { capitalization, usage, } \\
\text { paragraphing, grammar) }\end{array}$ & & $\begin{array}{l}\text { Errors may exist but are not } \\
\text { major (spelling, punctuation, } \\
\text { capitalization, usage, } \\
\text { paragraphing, grammar) }\end{array}$ & \\
\hline \multicolumn{5}{|c|}{$\begin{array}{l}\text { Scoring: Writers may receive a score of either } 2 \text { or } 4 \text { in any of the four dimensions when } \\
\text { writing shows characteristics from more than one column. For example, a writer's } \\
\text { organization may have an "effective sequence" (5) but the paper has a "weak start } \\
\text { or finish" (3); thus, the rating would be a "4" for Organization. }\end{array}$} & \\
\hline \multicolumn{6}{|c|}{$\begin{array}{l}\text { Total Possible Score } 20 \\
\text { Minimum Acceptable Score } 12 \\
\text { Please check the boxes below if you believe they apply. }\end{array}$} \\
\hline \multicolumn{6}{|c|}{$\square$ Automatic redo if the paper is not focused on the thesis. } \\
\hline \multicolumn{6}{|c|}{$\begin{array}{l}\square \text { Automatic redo if the paper has major paraphrasing violations. If you question the } \\
\text { authenticity of the student's work, please indicate the page numbers in question below. }\end{array}$} \\
\hline
\end{tabular}


original draft, which contained the many suggestions supplied by the preservice teachers from IPFW, the remaining students were able to achieve a higher measure of success. Significant improvement was measured: only 30 of the 180 students had to complete rewrites as contrasted to 90 percent during the previous year.

\section{Lessons for High School Students}

The Senior Project fosters rigorous research writing, including information literacy and knowledgeacquisition skills. The project fosters process writing that motivates students through topic choice and ongoing evaluation. The paper requires reflection, and the final, formal, oral presentation is evaluated by a team of judges, including professionals from the community. The Senior Project has a strong and positive impact on the students, teachers, and community. It is proving to meet the needs of a diverse student body and the demands for higher standards.

In our rural district, technology has been a boon for research. Technology allows students to complete research papers by retrieving textual resources through the Internet, accessing human resources through email, and creating PowerPoint presentations as students complete their Senior Project in our rural school district.

\section{Lessons for the High School Teachers}

During the presentation of the rubric to the preservice teachers in the fall 2002 term, Glenda posed a new issue for conversation-allowing students to write from the first-person point of view. She questioned if it was a matter of Indiana State Standards that papers were required to adhere to writing in the third person. I reflected on the basis for the requirement and admitted that it was more a matter of tradition than current English standards. Glenda, who is associate director of the Appleseed Writing Project-Indiana, an affiliate of the National Writing Project, introduced the concept of I-Search (Macrorie) as an alternative that allows students to research and write in the first person. She explained that, as a narrative re- searcher, she writes for professional publication in the first person. After reflecting on the idea, the high school English staff allowed some students, with teacher permission, to write in the first person when appropriate in discussing their personal involvement in the research process--research context, personal decision making, and research procedures. While the rubric was not changed, a waiver process was instituted to accommodate students whose project papers would be improved by a first-person narrative.

We have learned many other teaching lessons during the past five semesters. We have learned that we need to promote more aggressively the students' successes with the Senior Project. This will occur on the night of Project Fair, when students present the physical portion of the project. We also need to do a better job of indicating how this project is a topnotch way of reflecting Indiana State Standards. Written products over the past five semesters demonstrate improvement. When comparing the outcomes of the Senior Project with the Illinois state test's writing results, we believe the Senior Project is a better reflection of a student's academic ability.

We also learned that it is important for us to get more of the ENHS staff involved. The project has been centered in the English department, placing the weight of its success on the backs of four Senior English teachers and the fourteen or so other teachers who have volunteered to be a part of the Advisory Board, a decision-making panel with approval power over topic choices and thesis statements. The Senior Project has the potential to grow a culture of inquiry in our school as a whole—students, faculty, and community. Finally, we have learned that it is important for classroom teachers to have scholarly conversations about the state standards and our teaching practices and to conduct inquiry-based studies for ongoing decision making.

\section{Works Cited}

Chadwell, Deana R. "The Senior Project: South Medford High School-Medford, Oregon." Exemplary Practices in Education 1.4 (1992): 8-9.

Macrorie, Ken. The I-Search Paper. Rev. ed. Portsmouth: Boynton/Cook, 1988.

$\rightarrow$ Summers, Jane. "The Senior Project: A Walkabout to Excellence." English Journal 78.4 (1989): 62-64.

Matt Rickey received his bachelor's degree from Western Michigan University and his master's degree from Ball State University. He is in his twenty-fifth year of teaching at East Noble High School in Kendallville, Indiana. email: mrickey@eastnoble. net. Glenda Moss taught middle school students language arts skills for thirteen years in east Texas. She now prepares secondary classroom teachers in Indiana. email: mossg@ipfw.edu. 